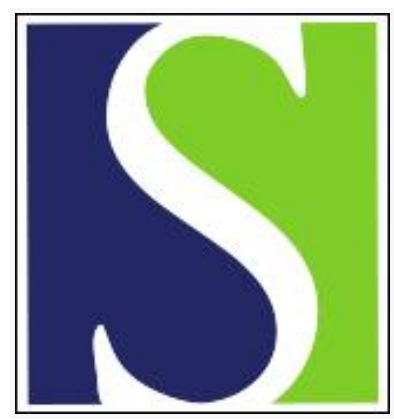

Scand J Work Environ Health 2014;40(4):400-410

https://doi.org/10.5271/sjweh.3430

Published online: 12 Apr 2014, Issue date: 01 Jul 2014

Role of the work-unit environment in the development of new shoulder pain among hospital workers: a longitudinal analysis by Lamy S, Descatha A, Sobaszek A, Caroly S, De Gaudemaris R, Lang $\mathrm{T}$

The prevention of musculoskeletal disorders among nurses is a major public health issue considering their important role in the healthcare system. This paper shows that, even if the collective stress factors at the work-unit level have no direct influence on shoulder pain, they may lead to working conditions with adverse direct effects on workers' risk of shoulder pain.

Affiliation: INSERM UMR 1027, Faculté de Médecine, 37 allées Jules Guesde, 31062 Toulouse Cedex, France. lamy_sebastien_emmanuel@hotmail.fr

Refers to the following texts of the Journal: 2001;27 suppl 1:1-102 2002;28(6):394-401 2006;32(4):285-293 2007;33(1):58-65 2010;36(3):189-201

Key terms: biomechanical exposure; hospital; hospital worker; longitudinal; longitudinal analysis; longitudinal study; MSD; musculoskeletal disorder; nurse; nursing; nursing assistant; pain; shoulder; shoulder pain; upper limb; work environment; work organization; work-related psychosocial stress; work-unit environment

This article in PubMed: www.ncbi.nlm.nih.gov/pubmed/24728032

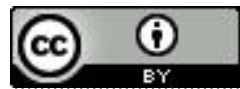




\title{
Role of the work-unit environment in the development of new shoulder pain among hospital workers: a longitudinal analysis
}

\author{
by Sébastien Lamy, PhD, 1,2 Alexis Descatha, PhD, , , 4, 5 Annie Sobaszek, PhD, ,, 7 Sandrine Caroly, PhD, ,, 9 \\ Régis De Gaudemaris, PhD, ${ }^{9,10}$ Thierry Lang, PhD ${ }^{1,2}$
}

\begin{abstract}
Lamy S, Descatha A, Sobaszek A, Caroly S, De Gaudemaris R, Lang T. Role of the work-unit environment in the development of new shoulder pain among hospital workers: a longitudinal analysis. Scand J Work Environ Health. 2014;40(4):400-410. doi:10.5271/sjweh.3430
\end{abstract}

\begin{abstract}
Objective This study aimed to test longitudinal associations linking the work-unit-level psychosocial and organizational work environment and biomechanical constraints to workers' shoulder pain in the French multi-centre cohort ORSOSA study of registered nurses (RN) and nursing assistants (NA).

Methods We analyzed 1896 female RN and NA, who were free of shoulder pain in 2006 and in the same position and work unit in 2008. Incident shoulder pain (SP) was defined as self-reported pain that persists for $\geq 4$ days and/or increases during a lateral movement of the arm away from the midline of the body (abduction). Both crosssectional and longitudinal models were built to test if work-unit-level features or their influences on both work tasks and individual perception of the work environment directly influence the risk of developing incident SP.

Results RN in work units with understaffing issues or poor relationships reported higher levels of biomechanical constraints in movements and postures and a lower level of perceived job security and stability. NA who experienced such issues reported higher levels of biomechanical constraints in indirect patient-handling activities only. The exposure to these latter factors was associated with higher two-year incident SP among workers.

Conclusion This study shows that the work-unit-level organizational characteristics may impact workers' musculoskeletal disorders by conditioning both work-task-related biomechanical exposures and individual perception of the working environment. In healthcare settings, primary prevention programs to reduce MSD would benefit from a focus on work unit level exposures.
\end{abstract}

Key terms biomechanical exposure; longitudinal study; musculoskeletal disorder; MSD; nurse; nursing; nursing assistant; upper limb; work environment; work organization; work-related psychosocial stress.

In many countries, upper-limb musculoskeletal disorders (MSD) are a major concern in the working population, and shoulder pain is the most frequent condition $(1,2)$. A recent worldwide systematic review of experimental and observational studies on nurses' physical health, shows that, with the exception of drivers and cleaning and maintenance personnel, nurses were more affected by MSD than other healthcare workers and other occupational groups (3). Considering nurses' important role in the healthcare system, preventing the development of MSD and the reduction of musculoskeletal symptoms among this occupational group is a major public health issue.

The role of the work environment in determining the occurrence of MSD is well documented in the literature.

1 Institut national de la santé et de la recherche médicale (INSERM) UMR 1027, Toulouse, France.

2 University of Toulouse 3, Paul Sabatier, UMR 1027, Toulouse, France.

3 University of Versailles St-Quentin, Versailles, France.

4 INSERM, Centre for research in Epidemiology and Population Health (CESP), U1018, "Population-Based Epidemiological Cohorts" Research Platform, Villejuif, France.

5 AP-HP, Occupational Health Unit/EMS (Samu92), University Hospital of Paris West suburb, Poincaré site, Garches, France.

6 CHRU Lille, Clinique de Santé Publique, Médecine du Travail et Pathologies Professionnelles, Lille, France.

7 University of Lille 2, Lille, France.

8 CNRS, UMR 5194, Laboratoire PACTE (Politiques Publiques, Action Publique, Territoires), Grenoble, France.

9 University of Grenoble, Grenoble, France.

${ }^{10}$ CNRS, UMR 5525, Laboratoire TIMC-IMAG, Equipe Environnement et Prédiction de la Santé des Populations, Grenoble, France.

Correspondence to: Sébastien Lamy, INSERM UMR 1027, Faculté de Médecine, 37 allées Jules Guesde, 31062 Toulouse Cedex, France. [E-mail: lamy_sebastien_emmanuel@hotmail.fr] 
Physical, and to a lesser extent psychosocial factors, have been identified as important risk factors of MSD $(1,4-9)$, including shoulder disorders $(2,10)$. Most of these studies examined the psychosocial work environment via work tasks, that is, at the individual level. Little concern has been given to the organizational context at the work-unit level and its possible importance for the primary prevention of MSD. Indeed, work-unit-level exposures may be seen as fundamental causes of adverse working conditions at the individual level that may lead to MSD. Among healthcare workers, few studies looked at the association between MSD and the organizational characteristics of the work environment, mainly focusing on shiftwork (7, 11). More recently, studies have addressed the effect of the perception of healthcare workers of the work-unitlevel psychosocial and organizational environment on the occurrence of MSD $(12,13)$, including MSD of the neck and shoulders (14). However, these studies were crosssectional and no conclusion could be drawn concerning causal relationships. Therefore, as McFarlane et al (15) concluded in their systematic literature review on the relationships between work-related psychosocial factors and MSD, further evidence is needed from new longitudinal studies to explore the temporal aspects of these links.

The present longitudinal study uses data from the French multicentre cohort study ORSOSA (ORganisation des SOins - SAnté des soignants), which aimed to examine associations between shoulder pain, biomechanical constraints, and work-unit-level psychosocial and organizational work environment in the ORSOSA cohort of registered nurses (RN) and nursing assistants (NA).

First, we tested the effects of the work-unit-level psychosocial and organization work environment on the development of incident shoulder pain (SP) among RN and NA. Secondly, we tested both cross-sectional and longitudinal associations between (i) the work-unit-level psychosocial and organization environment, and (ii) work tasks-related biomechanical exposures and individual perceptions of the psychosocial work environment. We hypothesized that work tasks and individual perceptions of the work environment may directly influence the risk of developing incident SP among workers without prior incident of SP (hypothesis 1). The workunit-level psychosocial and organizational environment may condition these latter factors (hypothesis 2).

\section{Methods}

\section{Population and study design}

The ORSOSA study is a national, longitudinal, multicentre study among seven French teaching hospitals $(16,17)$. It represents the first step of the ORSOSA interventional research program, developed in order to improve healthcare workers' psychosocial work environment (18). Work units were eligible if they accounted for $\geq 20$ nurses (RN or NA) and were not scheduled for closure in the following two years. From these, 210 work units, representative of hospital structure and management considerations, were randomly selected after stratification by the three specialty areas: (i) medicine, including geriatric, psychiatric and pediatric units; (ii) emergency or intensive care unit (ICU); and (iii) surgery. All nurses that worked at least halftime in the hospital in the selected work units were invited to participate. A maximum of $20 \mathrm{NA}$ and $\mathrm{RN}$ per unit were included in the ORSOSA cohort, on a random basis, representing a total of 4169 participants. Data on the work environment and workers' health were collected in 2006 and 2008. A total of 2915 female RN and NA were eligible for the present study as they were free of shoulder pain in 2006. Because longitudinal data were not available for those who changed work unit or position during the follow-up, we excluded $678 \mathrm{RN}$ and 341 NA resulting in a study sample of $1172 \mathrm{RN}$ and 724 NA (a total sample size of 1896). Workers with missing data concerning health status or work-unit-level environment or with confounding factors were excluded from the analyses.

\section{Data collection and variables}

Incident shoulder pain. In this study, incident shoulder pain (SP) was recorded with a self-administrated questionnaire derived from Kuorinka's general Standardized Nordic Questionnaire (19). Here, the human body (viewed from the back) is divided into nine anatomical regions. For each anatomical area, the following question is asked: "At any time during the last 7 days have you had trouble ache, pain, or discomfort?". We focused on pain or discomfort that persists in time for $\geq 4$ days and/or that increases during a lateral movement of the arm away from the midline of the body (abduction) (20). Indeed, shoulder pain during abduction of the arm $60-120^{\circ}$, known as painful arc, suggests a sub-acromial or rotator cull disorder (21). We used a binary variable for describing the presence or not of incident SP in 2008 among workers initially free of such pains in 2006.

Work tasks-related biomechanical exposures. The validated Borg rating of perceived exertion scale, ranging from 6-20 was used as a proxy for high physical exertion during a typical working day according to the main tasks (walking, running upstairs, patient handling activities, etc.) (22-24). The Borg score was used as a binary variable according to the median value [higher versus lower (reference)]. A self-administered questionnaire created by the French Musculoskeletal Disorders Surveillance Program, Pays de la Loire network, was 
used to assess Biomechanical work constraints (25). The questionnaire accounted for 13 items distributed among three dimensions: (i) Number of handling activities per day related to direct patient-handling activities [4 items, internal consistency indicated by Cronbach's alpha: 0.70 (RN) and 0.73 (NA)]; (iii) Number of handling activities per day related to indirect patient handling activities [3 items, Cronbach's alpha: 0.54 (RN) and 0.66 (NA)]; (iii) Movements and postures adopted in a typical work day with information about duration [6 items, Cronbach's alpha: $0.63(\mathrm{RN})$ and $0.67(\mathrm{NA})]$. The questionnaire is available online at www.orsosa.fr. Each dimension was coded as a binary variable. For a given dimension, workers were considered as exposed to a high level of constraints if the number of items coded "exposed" were higher than the number of items coded "unexposed".

Workers' perceived psychosocial work environment: the effort-reward imbalance model. We used the French version of the 23 Likert-scaled items standardized in Siegrist's effort-reward imbalance (ERI) questionnaire $(26,27)$. Effort comprised 6 items referring to the demanding aspects of the work environment, but we excluded the item concerning physical demand to avoid colinearity with the physical exertion variable. Reward comprised 11 items that encompassed 3 themes that may be labelled "perceived esteem and respect" (5 items), "job promotion and salary" (4 items), and "job security and stability" (2 items). We used each dimension as a continuous variable. Effort scores varied between 5-25, the higher the score, the higher the effort perception. Esteem and respect, job promotion and salary, and job security and stability scores varied between 5-25, 4-20, and $2-10$, respectively. The higher the score, the lower the reward perception for the dimension. Therefore, we consider these scores as an indication of a lack of reward and used them as continuous variables. The short version of the over-commitment scale was used to measure the worker's inability to withdraw from work obligations and develop a more distant attitude toward job requirements (6 items). High over commitment was used as a binary variable defined by the upper tertile of the distribution among the total female sample (27).

Work units' psychosocial and organizational work environment. We used the French validated 22-item Nursing Work Index-Extended Organization (NWI-EO) (16), which is an extended version of the widely used NWI-R (Nursing Work Index-Revised) (28). Two versions of the NWI-EO exist: one for RN and one for NA. Each item is evaluated on a 4-point Likert scale. Items are distributed among eights dimensions: (i) support from nursing management staff, (ii) staffing adequacy, (iii) information exchange regarding patient care encouraged by the organization, (iv) frequency of interruption during nursing tasks, (v) relationships with hierarchical superiors within the healthcare team, ie, the physician (for $\mathrm{RN}$ ) or the nurses (for NA), (vi) shared work values among members in the unit, (vii) support from administrative staff, and (viii) the ability to take holidays or paid leave (eg, when RN or NA have to come back to work during their days of rest). As work units form relatively homogeneous groups which have their own resources, supervisors and objectives, the NWI-EO dimensions for which the inter-rater reliability $(\operatorname{ICC}(1, k))$ was sufficiently high $(\geq 0.60)$ (29) were aggregated at the work unit level by averaging workers' scores of the same work unit. Scores obtained for each work-unit-level characteristic varied between $0-15$. For a given dimension, the higher the score, the more adverse the work-unit-level environment. For both RN and NA, six of the NWI-EO dimensions matched the $\operatorname{ICC}(1, k)$ condition: support from nursing management staff, staffing adequacy, information exchange regarding patient care encouraged by the organization, relationships with hierarchical superiors within the healthcare team, and the ability to take holidays or paid leave. The dimension "frequency of interruption during nursing tasks", also matched the ICC $(1, k)$ condition for RN but not NA. Aggregated measures were calculated separately for RN and NA. Scores were treated as continuous variables.

Associated factors. Models were stratified by occupation and adjusted for age, specialty of the work unit (medicine, emergency and intensive care, and surgery), work time and work schedule in 2006, even if they had no significant effect on the development of incident SP. We adjusted our models for work schedule because studies suggest that shift work is associated with several health issues among workers (30). Additionally, tobacco use (yes, no), body mass index (BMI) and physical activity $(<1$ hour a week, $\geq 1$ hour a week) in 2006 as these factors are known to be related with MSD (31-33).

\section{Data analysis}

In order to test the direct effects of adverse workrelated exposures on incident SP (hypothesis 1), we ran multivariate logistic regression models stratified by occupation to study the independent direct associations between work-related exposures at both the work unit and the worker levels in 2006 and workers' incident SP in 2008. These models were adjusted for work-unit specialty, work schedule, work time and known factors related to MSD (age, BMI, tobacco consumption and physical activity during leisure). From these models, the work-related exposures at the individual level, which have an independent longitudinal effect on workers' incident SP, were then used as dependent variables in a second step of the analysis. The retained variables were 
then used as outcome in models testing the effects of work-unit-level psychosocial and organizational environment in 2006 on work-task-related biomechanical exposures and individual perception of the work environment (hypothesis 2). We tested both cross-sectional relationships between work-unit-level psychosocial and organizational environment and work-related exposures assessed in 2006, and longitudinal relationships between work-unit-level psychosocial and organizational environment assessed in 2006 and work-related exposures were assessed in 2008. These models were adjusted for work-unit specialty, work schedule, work time, and age. The rationale behind this two-step analysis was the Baron \& Kenny definition of simple mediation (34). Thus, our assumption is that the work-unit-level psychosocial and organizational environment may influence incident SP through its association with work-related exposures at the individual level for which we showed direct effect on incident SP. Additionally, we assumed that if the individual perception may be influenced by both the work-unit-level environment and the worktask-related biomechanical exposures, the latter are less likely to be influenced by individual perception. Pearson correlation coefficients were computed for obtaining the pairwise correlation between the continuous scores of work-related exposures. Linear or logistic regression models were used according to the nature of the outcome variable. We tested the statistical significance of both random effects and fixed effects for the hospital and the work-unit level by comparing nested models with log-likelihood ratio tests. As no contextual effects were found for either the hospital or the work-unit level (data not shown), we did not adjust the models for these levels. In other words, we did not use random effects models but only linear or logistic regression models. Odds ratios (OR) with 95\% confidence interval (CI 95\%) are presented for each model. Bootstrap methods were used to estimate standard deviations and confidence intervals. As the multivariate regression models we built did not have the same outcomes, the analyzed sample size varied according to the inclusion criteria we defined at the end of the "population and study design" section. Here, we present inclusion rates only for the primary analysis that is where work units and work-related exposure in 2006 were related to incident SP in 2008. All analyses were performed using STATA, release 12 (StataCorp LP, College Station, TX, USA) with the "pwcorr', "regress", "logit", "xtmelogit", and "xtmixed" procedures.

The ethics committee of the Lille Centre Hospitalier Régional Universitaire (CHRU) approved the ORSOSA study. All the participants gave their written consent.

\section{Results}

Among the 1896 (1172 RN and 724 NA) workers initially eligible, 95\% were included in primary analyses (1119 $\mathrm{RN}$ and $682 \mathrm{NA}$ ). Baseline characteristics are presented in table 1. Eight workers were excluded due to missing data on incident SP in 2008 and 87 (49 RN and 38 NA) because of missing data on either confounding factors or exposure variables in 2006. No significant differences were found between workers included in analyses and those excluded $(\mathrm{N}=95)$ based on age, working time, work schedule, lifestyle, BMI and work-related exposures. However, compared to included RN, excluded $\mathrm{RN}$ worked mostly in emergency/ICU work units and reported lower physical exertion. Similarly, compared to their included counterparts, excluded NA reported higher level of constraint related to indirect patient handling activities (data not shown). Between 2006 and 2008, 168 $\mathrm{RN}$ and 144 NA reported incident SP. This corresponds to incidences rate of about $14.3 \%$ and $19.9 \%$, respectively, for the studied period (two years).

Among the analyzed sample, there were only weak linear correlations $(r \leq 0.30)$ between the continuous scores of work-related exposures in 2006 as it is shown in table 2. No crude effects (ie, not adjusted for other work-related exposures) were found linking work-unitlevel psychosocial and organizational constraints and incident SP (data not shown). First, in order to test the independent longitudinal effects of work-related exposures on workers' incident SP at two years, we built two logistical regression models, one per occupation, both adjusted for job and individual characteristics. These models, presented in table 3, show that there were no direct effects of work-unit-level psychosocial and organizational environment on workers' incident $\mathrm{SP}$ after two years among both RN and NA. Among $\mathrm{RN}$, incident SP was predicted by high constraints related to movements and postures adopted during the work activities, and perceived lack of job security and stability. Conversely, among NA, low incident SP was predicted by high constraints related to direct patient handling activities.

Second, we tested the effect of the work-unit-level psychosocial and organizational environment on work tasks-related biomechanical exposures and workers' perceived work environment through both cross-sectional (exposure and outcome in 2006) and longitudinal (exposure in 2006 and outcome in 2008) multivariate regression models. Among RN, table 4 presents the models linking the work-unit-level environment to the scores of biomechanical constraints related to movements and postures, after adjustment for work-unit specialty, work schedule, working time, and age. The cross-sectional analysis shows that the lower the staff adequacy, the 
Table 1. Baseline characteristics of the 1801 workers included in analyses. [SD=standard deviation; NWI-EO=work-unit-level psychosocial and organisational environment]

\begin{tabular}{|c|c|c|c|c|c|c|c|c|}
\hline \multirow[t]{2}{*}{$\begin{array}{l}\text { Workers and } \\
\text { position characteristics }\end{array}$} & \multicolumn{4}{|c|}{$\begin{array}{l}\text { Registered nurse } \\
(\mathrm{N}=1119)\end{array}$} & \multicolumn{4}{|c|}{$\begin{array}{c}\text { Nursing assistant } \\
(\mathrm{N}=682)\end{array}$} \\
\hline & Mean & SD & $\mathrm{N}$ & $\%$ & Mean & SD & $\mathrm{N}$ & $\%$ \\
\hline$\overline{\text { Age }}$ & 36 & 9.1 & & & 40 & 9.2 & & \\
\hline $\begin{array}{l}\text { Age (tertile) } \\
\text { T1 ( }<33 \text { years) } \\
\text { T2 ( } \leq 33-43 \text { years) } \\
\text { T3 ( } \leq 44 \text { years) }\end{array}$ & & & $\begin{array}{l}524 \\
337 \\
258\end{array}$ & $\begin{array}{l}47 \\
30 \\
23\end{array}$ & & & $\begin{array}{l}176 \\
221 \\
285\end{array}$ & $\begin{array}{l}26 \\
32 \\
42\end{array}$ \\
\hline $\begin{array}{l}\text { Work unit speciality } \\
\text { Intensive care units (ICU) } \\
\text { Medicine } \\
\text { Surgery }\end{array}$ & & & $\begin{array}{l}443 \\
344 \\
332\end{array}$ & $\begin{array}{l}40 \\
31 \\
30\end{array}$ & & & $\begin{array}{l}210 \\
250 \\
222\end{array}$ & $\begin{array}{l}31 \\
37 \\
33\end{array}$ \\
\hline $\begin{array}{l}\text { Working schedule } \\
\text { Day only } \\
\text { Alternate day-night or night only }\end{array}$ & & & $\begin{array}{l}464 \\
655\end{array}$ & $\begin{array}{l}41 \\
59\end{array}$ & & & $\begin{array}{l}467 \\
215\end{array}$ & $\begin{array}{l}68 \\
32\end{array}$ \\
\hline $\begin{array}{l}\text { Working time } \\
\text { Partial } \\
\text { Full }\end{array}$ & & & $\begin{array}{l}271 \\
848\end{array}$ & $\begin{array}{l}24 \\
76\end{array}$ & & & $\begin{array}{l}140 \\
542\end{array}$ & $\begin{array}{l}21 \\
79\end{array}$ \\
\hline $\begin{array}{l}\text { Leisure-time physical activity } \\
<1 \text { hour/week } \\
\geq 1 \text { hour/week }\end{array}$ & & & $\begin{array}{l}457 \\
662\end{array}$ & $\begin{array}{l}41 \\
59\end{array}$ & & & $\begin{array}{l}387 \\
295\end{array}$ & $\begin{array}{l}57 \\
43\end{array}$ \\
\hline $\begin{array}{l}\text { Tobacco consumption } \\
\text { No } \\
\text { Yes }\end{array}$ & & & $\begin{array}{l}830 \\
289\end{array}$ & $\begin{array}{l}74 \\
26\end{array}$ & & & $\begin{array}{l}460 \\
222\end{array}$ & $\begin{array}{l}67 \\
33\end{array}$ \\
\hline $\begin{array}{l}\text { Body mass index } \\
\text { Normal } \\
\text { Underweight } \\
\text { Overweight } \\
\text { Obese }\end{array}$ & & & $\begin{array}{r}831 \\
87 \\
143 \\
58\end{array}$ & $\begin{array}{r}74 \\
8 \\
13 \\
5\end{array}$ & & & $\begin{array}{r}445 \\
53 \\
131 \\
53\end{array}$ & $\begin{array}{r}65 \\
8 \\
19 \\
8\end{array}$ \\
\hline $\begin{array}{l}\text { Work-unit-level psychosocial and organizational } \\
\text { environment (NWI-E0) }(0-15 \text { scale) }\end{array}$ & & & & & & & & \\
\hline $\begin{array}{l}\text { Support from nursing management staff } \\
\text { Adequate staffing } \\
\text { Organization encouraging the exchange of } \\
\text { information regarding patient care }\end{array}$ & $\begin{array}{l}7 \\
9 \\
7\end{array}$ & $\begin{array}{l}2.3 \\
2.4 \\
1.3\end{array}$ & & & $\begin{array}{l}6 \\
9 \\
6\end{array}$ & $\begin{array}{l}2.0 \\
2.6 \\
1.3\end{array}$ & & \\
\hline $\begin{array}{l}\text { Interruptions during nursing tasks } \\
\text { Relationships with hierarchical superiors within } \\
\text { the healthcare team }\end{array}$ & $\begin{array}{r}11 \\
6\end{array}$ & $\begin{array}{l}1.5 \\
1.3\end{array}$ & & & 5 & 1.7 & & \\
\hline Ability to take holidays or paid leave & 7 & 1.8 & & & 7 & 1.7 & & \\
\hline $\begin{array}{l}\text { Biomechanical constraints (worker level) } \\
\text { Low physical exertion at work } \\
\text { High physical exertion at work } \\
\text { Low constraints in direct patient handling } \\
\text { High constraints in direct patient handling } \\
\text { Low constraints in indirect patient handling } \\
\text { High constraints in indirect patient handling } \\
\text { Low constraints in movements and postures } \\
\text { High constraints in movements and postures }\end{array}$ & & & $\begin{array}{r}599 \\
520 \\
1068 \\
51 \\
1069 \\
50 \\
990 \\
129\end{array}$ & $\begin{array}{r}54 \\
46 \\
95 \\
5 \\
96 \\
4 \\
88 \\
12\end{array}$ & & & $\begin{array}{r}228 \\
454 \\
546 \\
136 \\
636 \\
46 \\
529 \\
153\end{array}$ & $\begin{array}{r}33 \\
67 \\
80 \\
20 \\
93 \\
7 \\
78 \\
22\end{array}$ \\
\hline $\begin{array}{l}\text { Effort-reward perception (worker level) } \\
\text { Perceived effort ( } 5-25 \text { scale) } \\
\text { Perceived esteem and respect (5-25 scale) } \\
\text { Perceived career opportunity and salary (4-20 } \\
\text { scale) } \\
\text { Perceived job security and stability (2-10 scale) }\end{array}$ & $\begin{array}{r}18 \\
7 \\
8\end{array}$ & $\begin{array}{l}4.2 \\
2.7 \\
2.3 \\
\\
1.4\end{array}$ & & & $\begin{array}{r}16 \\
7 \\
7\end{array}$ & $\begin{array}{l}4.3 \\
2.4 \\
2.4 \\
1.6\end{array}$ & & \\
\hline $\begin{array}{l}\text { Low overcommitment } \\
\text { High overcommitment }\end{array}$ & & & $\begin{array}{l}695 \\
424\end{array}$ & $\begin{array}{l}62 \\
38\end{array}$ & & & $\begin{array}{l}488 \\
194\end{array}$ & $\begin{array}{l}72 \\
28\end{array}$ \\
\hline
\end{tabular}


Table 2. Pairwise correlation coefficients between continuous scores of work-related exposure among the analyzed sample ( $\mathrm{N}=1801)$. All correlation coefficients are statistically significant except those in bold. [NWI-EO=work-unit-level psychosocial and organizational environment]

\begin{tabular}{|c|c|c|c|c|c|c|c|c|c|c|c|c|c|c|c|c|c|c|c|}
\hline & \multicolumn{10}{|c|}{ Pairwise correlations among registered nurses ( $N=1119)$} & \multicolumn{9}{|c|}{ Pairwise correlations among nursing assistants (N=682) } \\
\hline & 1 & 2 & 3 & 4 & 5 & 6 & 7 & 8 & 9 & 10 & 1 & 2 & 3 & 4 & 5 & 6 & 7 & 8 & 9 \\
\hline \multicolumn{20}{|l|}{ NWI-EO } \\
\hline $\begin{array}{l}\text { Support from nursing } \\
\text { management staff }\end{array}$ & 1.000 & & & & & & & & & & 1.000 & & & & & & & & \\
\hline Adequate staffing & 0.294 & 1.000 & & & & & & & & & 0.208 & 1.000 & & & & & & & \\
\hline $\begin{array}{l}\text { Organization } \\
\text { encouraging the ex- } \\
\text { change of information } \\
\text { regarding patient care }\end{array}$ & 0.381 & 0.501 & 1.000 & & & & & & & & 0.483 & 0.487 & 1.000 & & & & & & \\
\hline $\begin{array}{l}\text { Interruptions during } \\
\text { nursing tasks }\end{array}$ & 0.200 & 0.456 & 0.529 & 1.000 & & & & & & & 0.192 & 0.141 & 0.166 & 1.000 & & & & & \\
\hline $\begin{array}{l}\text { Relationships with } \\
\text { hierarchical superiors } \\
\text { within the healthcare } \\
\text { team }\end{array}$ & 0.179 & 0.347 & 0.330 & 0.254 & 1.000 & & & & & & 0.356 & 0.401 & 0.438 & 0.115 & 1.000 & & & & \\
\hline $\begin{array}{l}\text { Ability to take } \\
\text { holidays or paid leave }\end{array}$ & 0.452 & 0.330 & 0.361 & 0.159 & 0.134 & 1.000 & & & & & 0.099 & 0.288 & $0.208-$ & -0.019 & 0.184 & 1.000 & & & \\
\hline \multicolumn{20}{|l|}{$\begin{array}{l}\text { Effort-reward } \\
\text { imbalance }\end{array}$} \\
\hline Perceived effort & 0.137 & 0.328 & 0.347 & 0.385 & 0.145 & 0.118 & 1.000 & & & & 0.266 & 0.083 & 0.138 & 0.063 & 0.182 & 0.172 & 1.000 & & \\
\hline $\begin{array}{l}\text { Perceived esteem } \\
\text { and respect }\end{array}$ & 0.245 & 0.105 & 0.166 & 0.093 & 0.190 & 0.102 & 0.216 & 1.000 & & & 0.127 & 0.062 & $0.135-$ & -0.005 & 0.093 & 0.207 & 0.3391 & 1.000 & \\
\hline $\begin{array}{l}\text { Perceived career } \\
\text { opportunity and } \\
\text { salary }\end{array}$ & 0.094 & 0.001 & 0.134 & 0.057 & 0.067 & 0.030 & 0.197 & 0.326 & 1.000 & & 0.060 & 0.106 & 0.097 & 0.0760 & 0.115 & 0.331 & 0.164 & 0.158 & 1.000 \\
\hline $\begin{array}{l}\text { Perceived job } \\
\text { security and stability }\end{array}$ & 0.068 & 0.069 & 0.090 & 0.061 & 0.112 & 0.045 & 0.233 & 0.231 & 0.179 & 1.000 & & & & & & & & & \\
\hline
\end{tabular}

higher the scores of biomechanical constraints related to movements and postures. The longitudinal analysis shows that the poorer the relationship with the hierarchical superior on the healthcare team, the higher the score of biomechanical constraints related to movements and postures. Table 5 presents the models linking the work-unit-level psychosocial and organizational work environment to the individual perception of a lack of job security and stability at work, independently of work-task-related biomechanical exposure and after adjustment for confounders. The cross sectional analysis shows that the poorer the quality of the relationship with the hierarchical superior on the healthcare team, the higher the perceived lack of job stability and security at work. The longitudinal analysis shows that the lower the staff adequacy, the lower the perceived lack of job stability and security at work, which may be translated by an increase in the feeling of being essential among workers and, thus, an increased feeling of security. Among NA, table 6 presents the models built to study the effects of the work-unit-level psychosocial and organizational environment on the scores of biomechanical constraints related to direct patients handling after adjustment for confounders. In both the cross-sectional and longitudinal analyses, we showed that that lower the staff adequacy, the higher the score of constraints related to direct patient handling.

\section{Discussion}

Our study suggests that the work-unit-level psychosocial and organizational environment did not directly influence workers' incident SP after two years, but acted as a fundamental determinant of both work-task-related biomechanical exposure and individual perceptions of effort and reward at work. Workers in work units with understaffing issues or poor relationships reported higher levels of biomechanical constraints in movements and postures among $\mathrm{RN}$ and indirect patient-handling activities among NA, and a lower level of perceived job security and stability among RN. The cross-sectional analyses showed that work-unit-level understaffing issues were linked to higher level of biomechanical constraints among both RN and NA, and that work-unitlevel relationship issues with the hierarchy were linked to higher perceived lack of job stability and security at work among RN. Longitudinal analyses showed that work-unit-level understaffing issues predicted higher levels of perceived lack of security and stability among RN and higher levels of biomechanical constraints among NA, and that work-unit-level relationship issues with the hierarchy predicted higher levels of biomechanical constraints among RN.

The main limitation of the present study is the attrition, inherent to cohort studies, which constrained us 
Table 3. Shoulder pain in 2008 in relation to exposures in 2006, that is, work-unit-level psychosocial and organizational environment (NWI-EO), biomechanical constraints, and individual perception of effort-reward imbalance at work. Logistic multivariate regression models stratified by occupation and adjusted for age, body mass index, work unit speciality, working time, work schedule, leisure-time physical activity, and tobacco consumption. [RN=registered nurse; NA=nursing assistant; $\mathrm{OR}=$ odds ratio; $95 \%$ $\mathrm{Cl}=95 \%$ confidence interval].

\begin{tabular}{|c|c|c|c|c|}
\hline \multirow[b]{3}{*}{ NWII-EO } & \multicolumn{2}{|c|}{$\begin{array}{c}\text { Model 1.1 } \\
\text { RN (N=1119) }\end{array}$} & \multicolumn{2}{|c|}{$\begin{array}{l}\text { Model } 2.1 \\
\text { NA }(\mathrm{N}=682)\end{array}$} \\
\hline & OR & $95 \% \mathrm{Cl}$ & OR & $95 \% \mathrm{Cl}$ \\
\hline & & & & \\
\hline $\begin{array}{l}\text { Support from nursing manage- } \\
\text { ment staff }\end{array}$ & 1.02 & $0.94-1.12$ & 1.04 & $0.91-1.18$ \\
\hline Adequate staffing & 0.98 & $0.90-1.07$ & 0.98 & $0.89-1.08$ \\
\hline $\begin{array}{l}\text { Organization encouraging the } \\
\text { exchange of information } \\
\text { regarding patient care }\end{array}$ & 1.12 & $0.96-1.31$ & 0.97 & $0.78-1.21$ \\
\hline Interruptions during nursing tasks & 0.90 & $0.77-1.05$ & & \\
\hline $\begin{array}{l}\text { Relationships with hierarchical } \\
\text { superiors within the healthcare } \\
\text { team }\end{array}$ & 1.15 & $0.95-1.38$ & 1.05 & $0.93-1.17$ \\
\hline $\begin{array}{l}\text { Ability to take holidays or paid } \\
\text { leave }\end{array}$ & 0.94 & $0.83-1.05$ & 0.94 & $0.80-1.11$ \\
\hline \multicolumn{5}{|l|}{$\begin{array}{l}\text { Biomechanical constraints } \\
\text { (worker level) }\end{array}$} \\
\hline Low physical exertion at work & 1 & & 1 & \\
\hline High physical exertion at work & 1.12 & $0.77-1.64$ & 1.00 & $0.62-1.61$ \\
\hline $\begin{array}{l}\text { Low constraints in direct } \\
\text { patient handling }\end{array}$ & 1 & & 1 & \\
\hline $\begin{array}{l}\text { High constraints in direct } \\
\text { patient handling }\end{array}$ & 0.85 & $0.34-2.12$ & 0.50 & $0.27-0.94$ \\
\hline $\begin{array}{l}\text { Low constraints in indirect } \\
\text { patient handling }\end{array}$ & 1 & & 1 & \\
\hline $\begin{array}{l}\text { High constraints in indirect } \\
\text { patient handling }\end{array}$ & 1.07 & $0.39-2.93$ & 1.60 & $0.72-3.55$ \\
\hline $\begin{array}{l}\text { Low constraints in movements } \\
\text { and postures }\end{array}$ & 1 & & 1 & \\
\hline $\begin{array}{l}\text { High constraints in movements } \\
\text { and postures }\end{array}$ & 1.61 & $1.05-2.45$ & a 1.46 & $0.92-2.33$ \\
\hline \multicolumn{5}{|l|}{$\begin{array}{l}\text { Effort-reward imbalance } \\
\text { (worker level) }\end{array}$} \\
\hline Perceived effort & 1.05 & $1.00-1.11$ & a 1.06 & $1.00-1.12$ \\
\hline $\begin{array}{l}\text { Perceived lack of esteem } \\
\text { and respect }\end{array}$ & 0.97 & $0.90-1.05$ & 0.92 & $0.81-1.03$ \\
\hline $\begin{array}{l}\text { Perceived lack of career } \\
\text { opportunity and salary }\end{array}$ & 1.04 & $0.96-1.13$ & 1.03 & $0.94-1.13$ \\
\hline $\begin{array}{l}\text { Perceived lack of job security } \\
\text { and stability }\end{array}$ & 1.15 & $1.02-1.29$ & a 1.04 & $0.91-1.18$ \\
\hline Low overcommitment & 1 & & 1 & \\
\hline High overcommitment & 0.95 & $0.63-1.43$ & 1.26 & $0.76-2.08$ \\
\hline
\end{tabular}

a $0.05>$ P-value $>0.01$.

to focus on workers who stayed in the study and did not change work unit or position during the follow-up $(\mathrm{N}=1896)$ therefore excluding the others $(\mathrm{N}=1019)$. This may lead to both possible healthy worker and survivor effects (35). However, the possible bias is limited, since we found only a few statistically significant differences at inclusion between the analyzed sample $(\mathrm{N}=1801)$ and the whole female sample initially free of shoulder pain, which was followed in the ORSOSA study $(\mathrm{N}=2915)$. In the studied sample, workers were older. RN worked slightly less full-time than NA, while NA worked less
Table 4. Constraints in movements and postures in 2006 (crosssectional analysis) and 2008 (Iongitudinal analysis) in relation with work-unit-level psychosocial and organizational environment (NWI-EO) among registered nurses in 2006. Models adjusted for work unit speciality, work schedule, working time, and age. [OR=odds ratios; $95 \% \mathrm{Cl}=95 \%$ confidence interval]

\begin{tabular}{|c|c|c|c|c|}
\hline & \multirow{2}{*}{\multicolumn{2}{|c|}{$\begin{array}{c}\begin{array}{c}\text { Constraints in } \\
\text { movements and } \\
\text { postures in } 2006\end{array} \\
\begin{array}{c}\text { Model 1.2 } \\
(\mathrm{N}=1119)\end{array} \\
\end{array}$}} & \multirow{2}{*}{\multicolumn{2}{|c|}{$\begin{array}{c}\text { Constraints in } \\
\text { movements and } \\
\text { postures in } 2008 \\
\text { Model 1.3 } \\
(\mathrm{N}=1112)\end{array}$}} \\
\hline & & & & \\
\hline & $\mathrm{OR}$ & $95 \% \mathrm{Cl}$ & $\mathrm{OR}$ & $95 \% \mathrm{Cl}$ \\
\hline $\begin{array}{l}\text { Support from nursing } \\
\text { management staff }\end{array}$ & 1.02 & $0.92-1.14$ & 1.02 & $0.94-1.11$ \\
\hline Adequate staffing & 1.09 & & 1.02 & \\
\hline $\begin{array}{l}\text { Organization encouraging the } \\
\text { exchange of information } \\
\text { regarding patient care }\end{array}$ & 0.99 & 0.79 & 1.03 & -1.24 \\
\hline Interruptions during nursing tasks & 1.16 & $0.96-1.39$ & 1.14 & $0.99-1.30$ \\
\hline $\begin{array}{l}\text { Relationships with hierarchical } \\
\text { superiors within the healthcare team }\end{array}$ & 0.97 & $0.80-1.18$ & 1.21 & $1.01-1.44$ a \\
\hline Ability to take holidays or paid leave & 0.96 & $0.85-1.08$ & 0.96 & $0.86-1.08$ \\
\hline
\end{tabular}

a $P$-value $<0.01$.

in alternate night/days or night-only shifts and reported fewer constraints related to patient direct handling.

In addition, the use of a Nordic-style self-reported questionnaire can be useful for epidemiologic surveillance, but a physical examination remains essential in order to formally diagnose MSD (19). This study focused on information about pain during the last seven days only, which may limit the results' interpretation regarding the known fluctuating nature of muscle pain (although we restrict the study to shoulder pain that persisted $\geq 4$ days or that was aggravated during the abduction of the arm).

Nevertheless, the present study has several strengths. We did not restrict our study to the direct longitudinal effects of work-unit-level work environment on workers' incident SP, independent of individual-level exposures. We also tested the relationships linking the work-unit-level psychosocial and organizational environment to work-task-related biomechanical exposures and individual perceptions of effort and reward at work. In making both cross-sectional and longitudinal analyses, we explored different time-lags for the effect of the work-unit-level environment. Moreover we used aggregated measures to describe the work-unit-level environment, as Aiken \& Hage (36) did when showing that employees in complex organizations can serve as reliable and valid informants concerning the presence of organizational traits. In contrast with studies that focused on work-stress models, such as Karasek's or Siegrist's models $(37,38)$, we also used the NWI-EO, a validated tool developed specifically for hospitals setting to help the improvement of the work environment (16). Our analyses are based on robust methods for the 
Table 5. Perceived lack of job security in 2006 (cross-sectiona analysis) and 2008 (longitudinal analysis) in relation to workunit-level psychosocial and organizational environment (NWI-EO) and biomechanical constraints among registered nurses in 2006 Linear multivariate regression models adjusted for work unit speciality, work schedule, working time and age. [RC=regression coefficient; $95 \% \mathrm{Cl}=95 \%$ confidence interval]

\begin{tabular}{|c|c|c|c|c|}
\hline & \multirow{2}{*}{\multicolumn{2}{|c|}{ 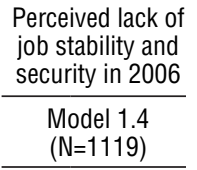 }} & \multirow{2}{*}{\multicolumn{2}{|c|}{$\begin{array}{c}\begin{array}{c}\text { Perceived lack of } \\
\text { job stability and } \\
\text { security in } 2008 \\
\text { Model 1.5 } \\
(\mathrm{N}=1114)\end{array} \\
\end{array}$}} \\
\hline & & & & \\
\hline & $\mathrm{RC}$ & $95 \% \mathrm{Cl}$ & $\mathrm{RC}$ & $95 \% \mathrm{Cl}$ \\
\hline \multicolumn{5}{|l|}{ NWI-EO } \\
\hline $\begin{array}{l}\text { Support from nursing } \\
\text { management staff }\end{array}$ & 0.02 & $-0.02-0.06$ & 0.03 & $-0.01-0.07$ \\
\hline Adequate staffing & 0.01 & $-0.05-0.04$ & -0.05 & $-0.09--0.01^{a}$ \\
\hline $\begin{array}{l}\text { Organisation encouraging } \\
\text { the exchange of information } \\
\text { regarding patient care }\end{array}$ & 0.03 & $-0.04-0.11$ & 0.04 & $-0.06-0.14$ \\
\hline $\begin{array}{l}\text { Interruptions during } \\
\text { nursing tasks }\end{array}$ & 0.02 & $-0.05-0.08$ & 0.04 & $-0.04-0.11$ \\
\hline $\begin{array}{l}\text { Relationships with } \\
\text { hierarchical superiors within } \\
\text { the healthcare team }\end{array}$ & 0.07 & $0.01-0.13^{a}$ & 0.02 & $-0.05-0.09$ \\
\hline $\begin{array}{l}\text { Ability to take holidays or } \\
\text { paid leave }\end{array}$ & 0.02 & $-0.02-0.06$ & 0.01 & $-0.04-0.07$ \\
\hline \multicolumn{5}{|l|}{$\begin{array}{l}\text { Biomechanical constraints } \\
\text { (worker level) }\end{array}$} \\
\hline Low physical exertion at work & 1.00 & & 1.00 & \\
\hline High physical exertion at work & 0.08 & $-0.10-0.26$ & -0.04 & $-0.22-0.14$ \\
\hline $\begin{array}{l}\text { Low constraints in } \\
\text { direct patient handling }\end{array}$ & 1.00 & & 1.00 & \\
\hline $\begin{array}{l}\text { High constraints in } \\
\text { direct patient handling }\end{array}$ & 0.07 & $-0.43-0.57$ & 0.053 & $-0.05-1.11$ \\
\hline $\begin{array}{l}\text { Low constraints in } \\
\text { indirect patient handling }\end{array}$ & 1.00 & & 1.00 & \\
\hline $\begin{array}{l}\text { High constraints in } \\
\text { indirect patient handling }\end{array}$ & -0.05 & $-0.52-0.41$ & -0.06 & $-0.57-0.44$ \\
\hline $\begin{array}{l}\text { Low constraints in } \\
\text { movements and postures }\end{array}$ & 1.00 & & 1.00 & \\
\hline $\begin{array}{l}\text { High constraints in } \\
\text { movements and postures }\end{array}$ & 0.16 & $-0.14-0.47$ & 0.29 & $-0.06-0.63$ \\
\hline
\end{tabular}

standard errors and the confidence interval estimations using a sample of $62 \%$ of all the female RN and NA free of shoulder pain on inclusion in the ORSOSA cohort.

Work-related MSD of the neck and shoulders are common among nursing personnel (8). Moreover, shoulder musculoskeletal symptoms are of major concern among nurses as they affect work activities and sleep quality with a dose-response relationship (39). Thus, in a recent systematic literature review of interventions that aim to reduce musculoskeletal symptoms in the healthcare sector, the authors recommended as "practice to consider" interventions that combine actions to change the work organization with actions to alter the work environment and workers' training. However, the authors consider that there is an insufficient level of evidence given the few high quality studies on this subject (40). Such studies require a better understanding of the mechanisms behind

Table 6. Constraints in direct patient handling in 2006 (crosssectional analysis) and 2008 (longitudinal analysis) in relation to work-unit-level psychosocial and organizational environment (NWI-EO) among nursing assistants in 2006. Logistic multivariate regression models adjusted for work unit speciality, work schedule, working time and age. [OR=odds ratio; $95 \% \mathrm{Cl}=95 \%$ confidence interval]

Support from nursing management staff

Adequate staffing

Organisation encouraging

the exchange of information

regarding patient care

Relationships with hierarchical

superiors within the healthcare

team

Ability to take holidays or paid leave

a P-value $<0.001$.

\begin{tabular}{|c|c|c|c|}
\hline \multicolumn{2}{|c|}{$\begin{array}{c}\text { Constraints } \\
\text { in direct patient } \\
\text { handling in } 2006\end{array}$} & \multicolumn{2}{|c|}{$\begin{array}{c}\text { Constraints } \\
\text { in direct patient } \\
\text { handling in } 2008\end{array}$} \\
\hline \multicolumn{2}{|c|}{$\begin{array}{c}\text { Model } 2.2 \\
(\mathrm{~N}=682)\end{array}$} & \multicolumn{2}{|c|}{$\begin{array}{c}\text { Model } 2.3 \\
(\mathrm{~N}=676)\end{array}$} \\
\hline OR & $95 \% \mathrm{Cl}$ & $\mathrm{OR}$ & $95 \% \mathrm{Cl}$ \\
\hline 0.89 & $0.79-1.01$ & 0.90 & $0.79-1.03$ \\
\hline 1.18 & $1.08-1.30^{\mathrm{a}}$ & 1.24 & 1.11 \\
\hline 1.07 & $0.85-1.34$ & 1.18 & $0.94-1.48$ \\
\hline 1.04 & $0.92-1.17$ & 1.11 & $0.98-1.25$ \\
\hline 0.94 & $0.82-1.08$ & 0.97 & $0.84-1.13$ \\
\hline
\end{tabular}
in direct patient in direct patient handling in 2006 handling in 2008

the role of the psychosocial and organizational context in the development of MSD. In 2012, Eatough et al (41) tested a model linking the psychosocial work environment to MSD through strain at work seen as individuals' maladaptive responses to environmental demands or stressors. Regarding shoulder symptoms, they showed that the relationships between safety-specific leadership and lower symptoms were fully mediated by strain, where safety-specific leadership referred to the extent to which the supervisors set safety-specific goals for staff rewarded safety-related behaviors, and coached employees to perform job tasks safely. However, this model was validated on cross-sectional data and the authors only focused on the more distal part of the causal chain linking workrelated exposure to workers' MSD (41). In our study, we focused on a more proximal part of the causal chain. We considered the work-unit-level psychosocial and organizational environment as the primary exposure in our analyses. In our approach, mediated pathways may link the work-unit-level environment to incident SP through work tasks-related constraints and individual perceptions of effort and reward at work.

The time lag (two years) for the direct effects of the work-unit-level psychosocial and organizational environment was in line with those found in many longitudinal studies exploring the relationships between psychosocial factors and MSD among healthcare workers which ranged from 1-3 years in a recent meta-analysis published on this topic (5). However, the studies reviewed in this work assessed psychosocial stressors at the worker level. In contrast, we studied psychoso- 
cial and organizational stressors at the work-unit level, which may require longer time-lags to reveal "visible" direct effects on MSD. This may explain why we did not find crude or direct effects of the work-unit-level psychosocial and organizational environment. In our study, working in work units with relationships or understaffing issues affected incident SP only through their effect on biomechanical constraints related to work tasks and individual perceptions of effort and reward at work. However, we found that the work-unit-level characteristics had an effect on worker-related constraints, which is consistent with the literature on healthcare workers. Indeed, a recent cross-sectional study showed that workunit-level understaffing issues were associated with higher MSD among hospital care workers even after adjustment for physical work but not after adjustment for worker-level psychosocial factors (12).

\section{Concluding remarks}

This study highlights the complexity of the relationships linking the work-unit-level psychosocial and organizational work environment to incident SP among hospital patient care workers. Results showed that workunit-level understaffing and relationship issues with the hierarchy on the healthcare team may influence work-related risk factors of incident SP among workers after two years. Our results showed that, in a hospital setting, the work-unit-level psychosocial and organizational environment may be seen as a determinant of working conditions by influencing both task-related biomechanical constraints and individual perceptions of the psychosocial environment. We argue that preventive interventions should consider and integrate psychosocial, biomechanical, and organizational factors. As such, epidemiological studies should include ergonomic observations in order to improve our understanding of the relationship linking work-related constraints to MSD and facilitate interventions to improve workers' health.

\section{Acknowledgments}

The authors would like to thank the other researchers involved in the ORSOSA Study. Coordinators: A Sobaszek, R de Gaudemaris. Scientific Board: T Lang; Groupe ORSOSA: V Bonneterre, F Balducci, S Caroly, V Ehlinger, L Larabi, JM Soulat, G Chatellier. Regional coordinators: JM Soulat, A Trichard, P Gabinski, M Druet-Cabanac, MC Vignaud, N Broessel; and research assistants: C Lecornet, J Goddard, M Tournegros, L Ferrand, I Kerjean, L Goddard, C Lecornet, M Le Guen, M Lorian, M Randrianarivo, M Dubuy, M Assimi, V Cottel, A Didry.
Caisse Nationale de Retraites des Agents des Collectivités Locales (CNRACL) supported this research. The CNRACL was not involved in the study design, data collection, analyses, data interpretation, or writing of the report. It had no influence over the decision to submit the paper for publication.

The authors declare no conflicts of interest.

\section{References}

1. Roquelaure Y, Ha C, Rouillon C, Fouquet N, Leclerc A, Descatha A, et al. Risk factors for upper-extremity musculoskeletal disorders in the working population. Arthritis Care Res. 2009;61(10):1425-34. http://dx.doi.org/10.1002/ art.24740.

2. van Rijn RM, Huisstede BMA, Koes BW, Burdorf A. Associations between work-related factors and specific disorders of the shoulder - a systematic review of the literature. Scand J Work Environ Health. 2010;36(3):189-201. http:// dx.doi.org/10.5271/sjweh.2895.

3. Fronteira I, Ferrinho P. Do nurses have a different physical health profile? A systematic review of experimental and observational studies on nurses' physical health. J Clin Nur. 2011;20(17-18):2404-24. http://dx.doi.org/10.1111/j.13652702.2011.03721.x

4. da Costa BR, Vieira ER. Risk Factors for Work-Related Musculoskeletal Disorders: A Systematic Review of Recent Longitudinal Studies. Am J Ind Med. 2010;53(3):285-323.

5. Lang J, Ochsmann E, Kraus T, Lang JWB. Psychosocial work stressors as antecedents of musculoskeletal problems: A systematic review and meta-analysis of stability-adjusted longitudinal studies. Soc Sci Med. 2012; 75(7):1163-74. http://dx.doi.org/10.1016/j.socscimed.2012.04.015.

6. Josephson M, Lagerstrom M, Hagberg M, Hjelm EW. Musculoskeletal symptoms and job strain among nursing personnel: a study over a three year period. Occup Environ Med. 1997;54(9):681-5. http://dx.doi.org/10.1136/ oem.54.9.681.

7. Myers D, Silverstein B, Nelson NA. Predictors of shoulder and back injuries in nursing home workers: A prospective study. Am J Ind Med. 2002;41(6):466-76. http://dx.doi. org/10.1002/ajim.10076.

8. Smedley J, Inskip H, Trevelyan F, Buckle P, Cooper C, Coggon D. Risk factors for incident neck and shoulder pain in hospital nurses. Occup Environ Med. 2003;60(11):864-9. http:// dx.doi.org/10.1136/oem.60.11.864.

9. Koehoorn M, Demers PA, Hertzman C, Village J, Kennedy SM. Work organization and musculoskeletal injuries among a cohort of healthcare workers. Scand J Work Environ Health. 2006;32(4):285-93. http://dx.doi.org/10.5271/sjweh.1012.

10. Bongers PM, Kremer AM, ter Laak J. Are psychosocial factors, risk factors for symptoms and signs of the shoulder, elbow, or hand/wrist?: A review of the epidemiological literature. Am J Ind Med. 2002;41(5):315-42. http://dx.doi.org/10.1002/ 
ajim.10050.

11. Lipscomb JA, Trinkoff AM, Geiger-Brown J, Brady B. Work-schedule characteristics and reported musculoskeletal disorders of registered nurses. Scand J Work Environ Health. 2002;28(6):394-401. http://dx.doi.org/10.5271/sjweh.691.

12. Kim S-S, Okechukwu C, Dennerlein J, Boden L, Hopcia K, Hashimoto D, et al. Association between perceived inadequate staffing and musculoskeletal pain among hospital patient care workers. Int Arch Occup Environ health. 2013;87(3):1-8.

13. Herin F, Paris C, Levant A, Vignaud MC, Sobaszek A, Soulat JM, et al. Links between nurses' organizational work environment and upper limb musculoskeletal symptoms: Independently of effort-reward imbalance! The ORSOSA study. Pain.2011;152(9):2006-15. http://dx.doi.org/10.1016/j. pain.2011.04.018.

14. Hoe VCW, Kelsall HL, Urquhart DM, Sim MR. Risk factors for musculoskeletal symptoms of the neck or shoulder alone or neck and shoulder among hospital nurses. Occup Environ Med. 2012;69(3):198-204. http://dx.doi.org/10.1136/ oemed-2011-100302.

15. Macfarlane GJ, Pallewatte N, Paudyal P, Blyth FM, Coggon $\mathrm{D}$, Crombez G, et al. Evaluation of work-related psychosocial factors and regional musculoskeletal pain: results from a EULAR Task Force. Ann Rheum Dis. 2009; 68(6):885-91. http://dx.doi.org/10.1136/ard.2008.090829.

16. Bonneterre V, Ehlinger V, Balducci F, Caroly S, Jolivet A, Sobaszek A, et al. Validation of an instrument for measuring psychosocial and organizational work constraints detrimental to health among hospital workers: The NWI-EO questionnaire. Int J Nurs Stud. 2011;48(5):557-67. http:// dx.doi.org/10.1016/j.ijnurstu.2010.09.006.

17. Trichard A, Vignaud MC, Herin F, Gabinski P, Broessel N, Druet-Cabanac PM, et al. Psychosocial and organizational factors at work (POW factors) among nurses and auxiliary nurses: Presentation of the ORSOSA study. Arch Mal Prof Env. 2009;70(1):28-35. http://dx.doi.org/10.1016/j. admp.2008.10.017.

18. Lamy S, de Gaudemaris R, Sobaszek A, Caroly S, Descatha A, Lang T. Améliorer les conditions de travail à l'hôpital: ORSOSA, de la démarche de recherche à l'action de prévention [improvement of hospital working conditions: ORSOSA, from research to preventive actions]. Sante Publique. 2013;25(4):389-97.

19. Descatha A, Roquelaure Y, Chastang JF, Evanoff B, Melchior $\mathrm{M}$, Mariot $\mathrm{C}$, et al. Validity of Nordic-style questionnaires in the surveillance of upper-limb work-related musculoskeletal disorders. Scand J Work Environ Health. 2007;33(1):58-65. http://dx.doi.org/10.5271/sjweh.1065.

20. Sluiter JK, Rest KM, Frings-Dresen MH. Criteria document for evaluating the work-relatedness of upper-extremity musculoskeletal disorders. Scand J Work Environ Health. 2001;27(Suppl 1):1-102. http://dx.doi.org/10.5271/sjweh.637.

21. Kessel L, Watson M. The painful arc syndrome. Clinical classification as a guide to management. Journal of Bone \& Joint Surgery. 1977;59-B(2):166-72.
22. Borg G. Perceived exertion as an indicator of somatic stress. Scand J Rehabil Med. 1970;2(2):92-8.

23. Chen MJ, Fan X, Moe ST. Criterion-related validity of the Borg ratings of perceived exertion scale in healthy individuals: a meta-analysis. J Sports Sci. 2002;20(11):873-99. http:// dx.doi.org/10.1080/026404102320761787.

24. Halson SL, Jeukendrup AE. Does Overtraining Exist? An Analysis of Overreaching and Overtraining Research. Sports Med. 2004;34(14):967-81. http://dx.doi. org/10.2165/00007256-200434140-00003.

25. Ha C, Roquelaure Y, Leclerc A, Touranchet A, Goldberg M, Imbernon E. The French Musculoskeletal Disorders Surveillance Program: Pays de la Loire network. Occup Environ Med. 2009;66(7):471-9. http://dx.doi.org/10.1136/ oem.2008.042812.

26. Niedhammer I, Siegrist J, Landre MF, Goldberg M, Leclerc A. Psychometric properties of the French version of the EffortReward Imbalance model. Rev Epidemiol Sante Publique. 2000;48(5):419-37.

27. Siegrist J, Starke S, Chandola T, Godin I, Marmot M, Niedhammer I, et al. The measurement of effort-reward imbalance at work: European comparisons. Soc Sci Med. 2004;58(8):1483-99. http://dx.doi.org/10.1016/S02779536(03)00351-4.

28. Aiken LH, Patrician PA. Measuring organizational traits of hospitals: The revised nursing work index. Nurs Res. 2000;49(3):146-53. http://dx.doi.org/10.1097/00006199200005000-00006.

29. Lake ET. Multilevel models in health outcomes research: Part II: Statistical and analytic issues. Appl Nurs Res. 2006;19(2):11315. http://dx.doi.org/10.1016/j.apnr.2006.01.001.

30. Muecke S. Effects of rotating night shifts: literature review. J Adv Nurs. 2005;50(4):433-9. http://dx.doi.org/10.1111/ j.1365-2648.2005.03409.x.

31. van den Heuvel SG, Heinrich J, Jans MP, van der Beek AJ, Bongers PM. The effect of physical activity in leisure time on neck and upper limb symptoms. Prev Med. 2005;(1):260-7. http://dx.doi.org/10.1016/j.ypmed.2004.11.006.

32. Palmer KT, Syddall H, Cooper C, Coggon D. Smoking and musculoskeletal disorders: findings from a British national survey. Ann Rheum Dis. 2003;62(1):33-6. http://dx.doi. org/10.1136/ard.62.1.33.

33. Viester L, Verhagen E, Hengel KM, Koppes L, van der Beek A, Bongers P. The relation between body mass index and musculoskeletal symptoms in the working population. Bmc Musculoskeletal Disorders. 2013;14(1):238. http://dx.doi. org/10.1186/1471-2474-14-238.

34. Baron RM, Kenny DA. The moderator-mediator variable distinction in social psychological research: conceptual, strategic, and statistical considerations. J Pers Soc Psychol. 1986;51(6):1173-82. http://dx.doi.org/10.1037/00223514.51.6.1173.

35. Goldberg M, Luce D. Les effets de sélection dans les cohortes épidémiologiques: Nature, causes et conséquences. [Selection effects in epidemiological cohorts: nature, causes and consequences]. Rev Epidemiol Sante Publique. 
2001;49(5):477-92.

36. Aiken M, Hage J. Organizational interdependence and intraorganizational structure. Am Sociol Rev. 1968;33:912-30. http://dx.doi.org/10.2307/2092683.

37. Karasek R, Brisson C, Kawakami N, Houtman I, Bongers P, Amick B. The Job Content Questionnaire (JCQ): an instrument for internationally comparative assessments of psychosocial job characteristics. J Occup Health Psychol. 1998;3(4):32255. http://dx.doi.org/10.1037/1076-8998.3.4.322.

38. Siegrist J. Adverse health effects of high-effort/low-reward conditions. J Occup Health Psychol. 1996;1(1):27-41. http:// dx.doi.org/10.1037/1076-8998.1.1.27.

39. Trinkoff AM, Lipscomb JA, Geiger-Brown J, Brady B. Musculoskeletal problems of the neck, shoulder, and back and functional consequences in nurses. Am J Ind Med. 2002;41(3):170-8. http://dx.doi.org/10.1002/ajim.10048.

40. Tullar JM, Brewer S, Amick BC, Irvin E, Mahood Q, Pompeii LA, et al. Occupational Safety and Health Interventions to Reduce Musculoskeletal Symptoms in the Healthcare Sector. J Occup Rehab. 2010;20(2):199-219. http://dx.doi. org/10.1007/s10926-010-9231-y.

41. Eatough EM, Way JD, Chang CH. Understanding the link between psychosocial work stressors and work-related musculoskeletal complaints. Appl Ergon. 2012;43(3):554-63. http://dx.doi.org/10.1016/j.apergo.2011.08.009.

Received for publication: 20 November 2013 